\title{
The Sustainable Success and Growth of Social Ventures: Their Internal and External Factors
}

\author{
Jisong Kim ${ }^{1}\left(\mathbb{D}\right.$, Jinhee Lee $^{2}$ and Timothy J. Lee ${ }^{3,4, *}$ \\ 1 Department of Economics, College of Economics \& Business Administration, The University of Suwon, \\ Hwaseong 18323, Korea; jisongkim@suwon.ac.kr \\ 2 Department of Tourism, Hanyang University, Seoul 04763, Korea; jhhi22@hanyang.ac.kr \\ 3 Faculty of Hospitality and Tourism Management, Macau University of Science and Technology (MUST), \\ Macao 999078, China \\ 4 Griffith Institute for Tourism (GIFT), Griffith Business School, Griffith University, \\ Nathan, QLD 4111, Australia \\ * Correspondence: timothy.lee@griffith.edu.au; Tel.: +61-7-5552-8139
}

Citation: Kim, J.; Lee, J.; Lee, T.J. The Sustainable Success and Growth of Social Ventures: Their Internal and External Factors. Sustainability 2021, 13, 5005. https://doi.org/10.3390/ su13095005

Academic Editors: Carlos Lopez-

Gutierrez, Ana Fernandez-Laviada and Andrea Pérez

Received: 26 March 2021

Accepted: 26 April 2021

Published: 29 April 2021

Publisher's Note: MDPI stays neutral with regard to jurisdictional claims in published maps and institutional affiliations.

Copyright: (c) 2021 by the authors. Licensee MDPI, Basel, Switzerland. This article is an open access article distributed under the terms and conditions of the Creative Commons Attribution (CC BY) license (https:// creativecommons.org/licenses/by/ $4.0 /)$.

\begin{abstract}
The social venture ecosystem is important for the growth and sustainability of social ventures. This study aims to expand our understanding of the sustainable success and growth of social ventures by analyzing both their internal and external factors using interviews with social venture entrepreneurs and stakeholders in the ecosystem. A qualitative research method is employed to examine the interviewees' perspectives, and the data were analyzed using the framework of grounded theory. The three-step grounded theory process was performed via open coding, axial coding, and selective coding. The study findings are drawn by organizing the outline according to this coding method. Entrepreneurs' awareness and willingness to solve social problems led to a sense of challenge, and the formation and maintenance of business models in the preparation stage positively affected the performance of social ventures through internal corporate resources and external cooperation. The study is of academic significance in that it presents a diversified dynamic concept of sustainability of social ventures compared to previous studies, which have been only fragmented studies. It also presents a number of managerial implications for sustainable development and the constant growth of social ventures.
\end{abstract}

Keywords: grounded theory; social venture; sustainable ecosystem; sustainability; Korea

\section{Introduction}

The international community is focusing on fostering social ventures while shifting the global socio-economic paradigm towards social change. The United Nations has been preparing action plans since 2013 to foster social ventures as a key driver for achieving its Sustainable Development Goals (SDGs). The "Entrepreneur of Social Change" project, which aims to promote positive social change in the community through entrepreneurship and innovative business ideas as a key practice of the UN SDGs, spent a total of $\$ 1$ million to recruit, educate, train, and mentor a total of 375 young (18-35-year-old) social entrepreneurs from 2013-2016 to help grow their social ventures. The European Union's Social Business Initiative has worked closely with EU countries to establish policies to create an environment where social ventures can be established and developed and has put forward policy recommendations for social and economic growth to develop public policies for these ventures in each member country. To this end, impact investment funds have been created, methods have been developed to measure social influence, public purchase opportunities have been expanded, and access to funds improved [1].

Discussion on the social economy has emerged in the international community, with much discourse taking place in fields that do not belong exclusively in either the private or public sector. Today, these areas are being presented as new alternative models for 
solving social problems [2]. Social ventures in Korea have recently come into the spotlight due to both their social and economic performance. In fact, social ventures that have been successful not only generate high financial returns through the commercialization of innovation but also actively realize social goals such as creating jobs for young people and effectively solving social problems. The emergence of social ventures in Korea began with the concerns about the aging of existing social and economic players around 2006 [3]. It was introduced and institutionalized by the government holding nationwide social venture competitions. Before the advent of social ventures, the government led efforts to solve social problems under the name of social enterprises, but they have been unable to overcome their dependence on the public sector, resulting in poor management performance as independent entities $[4,5]$.

The subset of companies that are run in venturous ways, such as through technology or management innovation while simultaneously pursuing social values and economic benefits, are called "social ventures". Since social ventures do not necessarily receive state certification, their number cannot be clearly determined. Thus, only a tentative estimate based on startups that independently pursue social ventures is available. This estimate can be made by considering social ventures that have received impact investments and have been supported by intermediary agencies, which resulted in an estimated 600 social ventures in Korea as of 2018 [6].

Social ventures have continued to grow in recent years, suggesting that this could be an important catalyst for revitalizing Korea's social economy. However, there is still a lack of objective data on social entrepreneurs and social ventures, and reliable research and policy support for individual companies. Much research and support for social ventures and social entrepreneurs aimed at social innovation is still insufficient. Furthermore, the scope and standards of social venture ecosystems are ambiguous; thus, there are restrictions and limitations on central or local government-level support. As Korea has a short history of social ventures, there are, as yet, few studies related to domestic ventures, and most studies of their success factors have focused on entrepreneurship and technical competence [4]. To supplement the limitations of existing research, this study aims to analyze the formation, maintenance and development of social ventures based on the experiences of entrepreneurs, employees and stakeholders and the further establishment of successful ecosystems. The purpose of this study is to first summarize the concept of social ventures that has not yet been clearly established and to understand the characteristics and status of Korean social ventures. Second, it is to investigate the process of establishing and developing social ventures based on the experiences of each stakeholder and to explore their roles, including entrepreneurs, employees, impact investors and government oriented intermediary agents in the factors that are needed to build a sustainable and successful ecosystem.

A qualitative research method was employed to examine the perspectives of social venture entrepreneurs and stakeholders. Through in-depth interviews with social venture entrepreneurs and employees, the capabilities and responsibilities of social ventures will be investigated both internally and externally. Moreover, the study explores how internal and external factors can affect the formation, maintenance, and development of social ventures by interviewing stakeholders. Internal factors include corporate resources and the capacity of the entrepreneur, and external factors encompass cooperation and networking with various institutions. Finally, the role of governments and impact investors in establishing a sustainable ecosystem is discussed.

Thereafter, the data were analyzed using the framework of grounded theory. The three-step coding process of grounded theory was performed via open coding, axial coding, and selective coding, and the study's conclusions were drawn by organizing the results according to this coding method [7-9]. The research results show that the entrepreneurship to solve social problems is an important aspect for social ventures to secure sustainable development and further succeed. However, networks with both internal corporate resources, external networks, and cooperation with various stakeholders have been identified as factors that can build a sustainable social venture ecosystem. Above 
all, the research provides both theoretical and managerial implications for the successful establishment of an ecosystem of social ventures. This paper proceeds as follows: the following section provides an overview of the extant research on the theoretical foundations of the main concepts. The research design, including research methods, case selection, and data collection, is then discussed. Next, the results of the data analysis are presented, and, finally, the theoretical and managerial implications and the limitations of the research are detailed.

\section{Literature Review}

\subsection{The Social Venture Concept}

The main elements that characterize social ventures are their pursuit of social objectives, entrepreneurial attributes based on innovation, company sustainability and growth, and financial returns [10]. Just as the concepts and definitions of the social economy varies from country to country depending on the literature, so do the definitions of social ventures. The United Kingdom defines social ventures as organizations or entities that seek the financial return of investors for the realization of social objectives or the resolution of social problems, regardless of their legal form. On the other hand, the United States defines social ventures as business ventures that promote social values through operations based on social objectives, economic principles, and innovation to alleviate or reduce social problems or market failures [11,12].

As an alternative, the term "social venture" is sometimes used as a relative concept that can compensate for the limitations of venture companies that lack sustainability and growth and pursue profits in economic terms, which are the main purposes of corporate management [13]. Haugh [14] and Hockerts [15] explained that social ventures operate as business ventures that create social value by carrying out innovative activities to solve social problems, while Dees and Anderson [16] defined social ventures as legally profitoriented corporations, such as stock companies, that are explicitly designed to address social concerns while generating revenue. Alter [17] defined social ventures as a form of hybrid organization. Hybrid organizations create social and economic value and are organized according to degree of activity in relation to motivation, accountability, and use of income. On the right-hand side of the hybrid spectrum is the for-profit corporation, whose main motive is to generate profits and distribute them to shareholders. On the lefthand side is a nonprofit organization engaged in commercial activities to fund programs to solve social problems and create social value.

The main role of social ventures is not to maximize profits but to help the socially vulnerable and mitigate unemployment by pursuing economic, social, or environmental goals or by combining them [17]. Revenues generated by social ventures should be reinvested to promote corporate purposes, such as research and development (R\&D) or organizational development or distributed as subsidies to local residents or communities [14]. By using entrepreneurial solutions to achieve social progress rather than shareholder interests [18], social ventures play a valuable role in creating a potentially sustainable and socially inclusive economy. Social ventures share the social or civic orientation of other nonprofit organizations but differ in their strategies, norms, values, etc., [19]. They use market-based solutions and innovative business models to pursue commercial and financial sustainability, and this differs from most nonprofit organizations that traditionally rely on charitable donations for income [20].

Given that innovation is a key factor that determines the sustainability of social venture activities and the solvability of social problem solving, the characteristics and definitions of social ventures need to be identified from an entrepreneur's perspective, which is a major role in innovation performance. Looking at recent trends in innovation, taking risks in this area is not a problem. In the past, innovation referred to the field of technology, but it has been recently expanded to nontechnical areas such as markets, organizations, and networks. Moreover, as innovative ideas increase the different types of collaboration in the field increase [5]. 
The OECD (2010) Innovation Strategy Report shows that people are at the center of the innovation process. The key issues in the transformation environment are that the person who is driving the innovation is innovative in nontechnical areas, there is increased complexity in the innovation process, and there is open innovation through cooperation [21]. In other words, innovative entrepreneurs and innovative entrepreneurship are critical, which means that no matter how good an innovation environment is, it's hard to succeed if there is no one to innovate. The characteristics of the innovative social entrepreneur are taking high-risk and high return, showing commitment and leadership, thinking strategically, creating values and opportunities, and being consistent in any circumstances [22,23]. Compared to profit-oriented entrepreneurs, social entrepreneurs face a higher risk of failure, but concerns and fears about failure even stimulate social entrepreneurs to challenge the status quo since they have a strong motivation [24,25].

\subsection{Social Ventures in Korea}

Social ventures emerged in Korea around 2006 as a way to solve the problem of generational succession due to concerns over the aging of existing social and economic players. Recently, social ventures have become increasingly recognized as social and economic entities. Social ventures are not just about finding social problems that have not been solved by the government or market, but rather about finding solutions and positively changing the world, which is becoming increasingly important in modern society [26]. Starting with the "First Social Venture Competition" in 2009, the government officially began using the term "social venture" [5]. On the other hand, according to the Small and Medium Business Administration (SMB), social ventures can be defined as "ventures to solve social problems," and their biggest difference from nonprofit organization is that they guarantee "risk-taking in account scalability" and have characteristics of innovation and high-risk (uncertain) high yield [6]. While the social role that general ventures play is the result of selling product services, social ventures are clearly set up to solve social problems and create social values. Table 1 illustrates the differences between social ventures and general ventures in Korea.

Table 1. Differences between social ventures and venture companies in Korea.

\begin{tabular}{|c|c|c|}
\hline Category & Social Venture & (General) Venture \\
\hline Mission & $\begin{array}{l}\text { Economic, social and/or } \\
\text { environmental value }\end{array}$ & $\begin{array}{l}\text { Market driven } \\
\text { Economic value } \\
\text { Financial surplus }\end{array}$ \\
\hline Pros and cons & $\begin{array}{l}\text { Creates high returns and } \\
\text { sustainable social impact if } \\
\text { successful }\end{array}$ & $\begin{array}{l}\text { Success generates high returns } \\
\text { but lacks social influence }\end{array}$ \\
\hline Main financial source & $\begin{array}{l}\text { Impact investment, social } \\
\text { finance, etc. }\end{array}$ & Venture capital, stocks, etc. \\
\hline Business model & $\begin{array}{l}\text { The business model of social } \\
\text { innovation } \\
\text { Impact investment model }\end{array}$ & $\begin{array}{l}\text { Efficiency-based revenue model } \\
\text { Venture capital investment model }\end{array}$ \\
\hline Entrepreneur activities & $\begin{array}{l}\text { Trading to achieve mission and } \\
\text { generate surplus }\end{array}$ & Trading to generate profit \\
\hline
\end{tabular}

In Korea, the characteristics of domestic social ventures are generally understood as follows. First, social ventures pursue strategic niche management as part of their social nature. Niche can be referred to a narrowing the gap in the society by solving the social problem in an innovative way. In other words, social ventures discover service that had been ignored by commercial companies due to small market sizes or insufficient growth. Social ventures play a role in discovering and developing social markets and forming and developing niches [27]. For example, Tree Planet has a project to create 
forests through crowdfunding to solve the desertification phenomenon in Korea, and HDM offers educational opportunities to young people who are in need through postpaid education services.

Second, funding is most importantly needed to maintain sustainability. Social ventures require impact investment at a different level than social support like NGOs. Since social ventures seek business feasibility, the business life cycle is similar to that of venture companies. For social ventures, there is a need for institutional support to operate sustainably beyond the 'death's valley' that appears after starting a business. Therefore, a social impact investment system based on social nature is essential [28].

Third, support from intermediary agencies is especially important in establishing and operating social ventures. An intermediary agency is an organization that links demand in areas where access is difficult under the existing system to policies and forms a network of relations within the community. The ministries and companies that act as intermediaries have long been working at their roles, but they have neither been integrated nor conceptualized in the academic literature. As social ventures increase and government interest increases, the role of intermediate organizations is also drawing attention [29].

\subsection{Sustainable Ecosystem of Social Ventures}

In a business or economy, the term "ecosystem" is used to describe a system in which various autonomous entities work together organically. Until now, Korea's social economy has been fostered via government initiative and various institutional and financial support mechanisms. Public-led policies with this clear purpose have the advantage of achieving quantitative growth in the near future; however, the present ecosystem has been considered to be problematic given that it is not suitable for building an innovative environment where new social ventures can continue to emerge [30]. Nevertheless, little academic research has focused on the ecosystem of social ventures.

As part of the wider social ecosystem, the social venture ecosystem is an environment in which social ventures can grow made up of a network system between various stakeholders. In other words, it is a network system in which various stakeholders form a virtuous circle of symbiosis and coexistence in order to produce socially innovative value complexes in all business-appropriate spaces. The social venture ecosystem consists largely of various capital infrastructures and socio-economic, cultural environmental spaces that help social ventures succeed. The capital infrastructure comprises human, social, political, financial, and knowledge capital. In addition, socio-economic and cultural environmental factors encompass social venture policies, media publicity, cultural awareness, economic and social conditions, and related fields [30,31]. Porter [32] described the ecosystem of enterprises from the perspective of a network that is created in enterprise clusters. According to Porter's corporate cluster theory, companies are concentrated in certain areas because implicit exchanges are subject to regional restrictions. For example, companies concentrated in Silicon Valley gain an advantage through knowledge exchange that other, more widely distributed companies do not: what is important in this clustering is that it is a network formed within a certain proximity.

The "social innovation cluster" proposed by Tanimoto [33] is based on Porter's [32] cluster theory and includes the same basic features but differs in some respects. First, social innovation clusters cover a variety of fields to create new ideas without limiting themselves to any specific one. Second, to create and develop various ideas and social values is to move away from geographical constraints. In other words, geographical concentration occurs in a particular area, but open space is sought instead of being limited to a specific area. Third, social ventures' interactions with local communities are important to inform citizens of their social values as there cannot be any social ventures that are not acceptable to the community. For example, network effects in 'Social Venture Valley', which consists of various social ventures and related agencies have started to appear. In the Seongsu-dong area in Seoul, social ventures aim to provide social services to the community through establishing their own community networks and collaborative and linked activities using 
those networks. In addition, various facilities such as impact investment companies and intermediary agencies seeking similar social missions have been introduced, showing effects such as improving the physical environment and revitalizing streets [34].

In terms of network establishment, building a cluster of social ventures is critical, but the formation of a sustainable ecosystem will be more urgent than anything else. In fact, when trying to create social innovation in social ventures, this is often stranded due to external influences. For example, even if certain technologies are developed, services cannot be realized unless human resource training, safety standards and policies are established. Therefore, it is necessary to analyze what roles and strategies each stakeholder of the relevant social venture ecosystem has, as well as social ventures that design and operate service models [35]. In other words, it is important to supplement not only the role of social ventures but also the role of surrounding stakeholders.

Following this trend, the EU devised an ecosystem model through the TEPSIE (theoretical, empirical and policy foundation for building social innovation in Europe) project to look at the structure of social innovation entities at all levels of society, and suggested a social innovation ecosystem, believing that the success and spread of social innovation depends on an effective surrounding environment. This social innovation ecosystem comprises four components: the structural environment, the supply and demand of innovation, and the intermediaries. The structural environment includes the economic environment, human resources, and the legal and institutional environment in the political and social context. Innovation supply refers to financial support such as investment and finance, nonfinancial support such as incubation, and proficiency courses for innovation such as university education. Demand for innovation means the expansion of consumers, including public procurement and campaigns, the establishment of systems such as subsidies and cluster policies, the establishment of open data, and the measurement of social impact. Intermediaries are organizations that provide the necessary functions of supply and demand through various programs and serve as a platform for networking and information exchange [36].

In the social innovation ecosystem, it is believed that the production and spread of innovative goods and services are possible through increased supply and increased demand. In particular, for the smooth operation of systems within an ecosystem, intermediaries should communicate their knowledge of social innovation and link the tangible and intangible resources required by social innovators. The TEPSIE (2014) ecosystem model has implications in that it proposes the concept and importance of intermediary agencies in the newly emerging social innovation ecosystem. But further discussion about how the intermediary agencies can be subdivided and what their role can be is necessary [36,37].

The role of players participating in the impact investment market is very important because the social venture ecosystem is constructed through private investment. Wilson [38] recognized that impact investment transactions exist at the core of the social enterprise ecosystem and that fostering social enterprises is possible when promoting these impact investment markets. In particular, the role of intermediaries in mediating the demand and supply of impact investments is more significant than that of social enterprises in the social venture ecosystem [39]. The intermediaries of the social venture ecosystem are largely related to knowledge, manpower, networking, marketing, innovation, finance, etc., and function as catalysts that facilitate the operation of the innovation and market ecosystems and co-evolution between organizations.

Social ventures find it difficult to achieve continuous growth in the fierce competitive market because they need to generate profits as well as achieve social goals. Furthermore, many social ventures have structural limitations such as small size, low quality of employees, labor-oriented production structures, and low management efficiency. Thus, to overcome these limitations and achieve sustainable growth, entrepreneurs must maximize their internal resources, such as knowledge and technology, from the beginning, while increasing their chances of success with network capabilities that lead to cooperation with external organizations [40,41]. Considering these aspects, in-depth interviews of social 
venture entrepreneurs, employees, impact investors, and intermediary agents to be done to understand the formation and maintaining of social ventures based on their experiences. The factors that are needed for a successful and sustainable social venture ecosystem are discussed in the following sections of the paper.

\section{Methods}

\subsection{Research Design}

This study was conducted using the framework of Strauss and Corbin's grounded theory [8]. This theory comprises a systematic inductive methodology that builds theories through the analysis and summary of data. Grounded theory is similar to other qualitative research methods in terms of its analytical approach to qualitative data; however, it is the most solid of these methods and is distinguished by the fact that it derives the theory itself [42]. In addition, unlike other qualitative methods, specific research processes can be performed that reduce the subjectivity of researchers and the ambiguity of data analysis, which are considered to be disadvantages of qualitative research. An inductive research method was appropriate to use in this study as it can explain the process of formation, maintenance and development of social ventures based on the experiences of people involved in these ventures. Grounded theory is a research method that can form a theoretical foundation when the theoretical background is not sufficient [43].

Grounded theory involves the analysis of in-depth interview data through open, axial, and then selective coding, and a paradigm model is created accordingly. The coding process is used to analyze interview records and create concepts, while the interview material is presented separately through words, sentences, and paragraphs. In the present study, the data collected through in-depth interviews were analyzed based on grounded theory to determine the necessary factors for the formation of a sustainable ecosystem for social ventures in Korea. The factors that guarantee the sustainability of social ventures have not yet been fully reviewed, and the success factors of social ventures are complex and interrelated. It is difficult to study such in-depth internal and external factors through traditional hypothesis testing; therefore, in this respect, grounded theory is suitable for analyzing the present study's data and deriving new and in-depth insights.

\subsection{Case Selection and Data Acquisition}

Data were collected through in-depth interviews with social venture entrepreneurs, employees, and stakeholders. In this study, the concepts constructed in the theoretical background were summarized and the participants were selected based on them. A snowball sampling method was then used to gather subsequent participants via introductions from the interview participants. Snowball sampling is often used when the population being surveyed is difficult to reach due to a small number of potential participants or when topics are sensitive [44]. In snowball sampling, the researcher judges whether it is suitable as a theoretical sample. The first few interviewees were acquaintances of one of the researchers and were working in a Korean social venture at the time of the interviews. They were able to recruit additional interview participants through their social networks. In total, 16 respondents were carefully selected in the field of social ventures, impact investments and intermediary agencies to reflect the environments of social venture sector. The types of social ventures were varied and included an ecofriendly firm, F\&B company in Africa, a transportation service in Africa, a fair-trade coffee business in developing countries, education services for low-income groups, and an IT businesses for disabled people. Participants working in impact investment and intermediary agencies were experienced in the field, having worked in it for at least one year to over fifteen years.

Prior to the full-scale interview, orientation and an exploration of the qualitative research methods were carried out, as well as the preparation of interview questionnaires, collecting of resources on social ventures, and practicing of interview techniques. This preparation was designed to improve the reliability of the qualitative research through acquiring interview guidelines [8]. The in-depth interviews were held mostly at the offices 
of the social ventures, impact investors, and intermediary organizations from 6 August- 6 October 2019. Before the interviews, the research participants were fully informed of the purpose of the research. After the interview the transcript was organized, and further interviews were conducted if additional data collection was deemed necessary due to any ambiguity. The interview was discontinued when the content reached saturation and no new content was visible. Semistructured questionnaires were used in the interviews with the 16 interviewees, with interview questions (see the Appendix A) designed to suit the researchers' purposes. Semistructured questionnaires consistently use interview guidelines to enable specific testimony and facilitate the structure of the material [45].

The researchers induced participants to respond by creating a comfortable atmosphere and by adding additional explanations when short answers from the participants made data collection difficult, ensuring that participants could fully talk about the topic. The collected data were managed and stored with a code, and the recorded file was repeatedly listened to in order to focus on voice changes and nuances. The researchers tried to minimize interpretation errors to ensure the reliability and validity of the collected data by applying the constant comparison method. This method is a process of conceptualizing the collected data several times in order to minimize the subjective judgment of the researchers during the analysis of direct research [8]. In so doing, the researchers were able to minimize errors and draw clear conclusions about the success factors for social ventures and the creation of ecosystems. The collected data were analyzed using Nvivo 12. Table 2 shows the characteristics of all interviewees in the study.

Table 2. Interviewee characteristics.

\begin{tabular}{|c|c|c|c|c|c|}
\hline Interviewee & Business Type & Title & $\begin{array}{c}\text { Period of } \\
\text { Employment }\end{array}$ & Gender & Age \\
\hline $\mathrm{A}$ & Social venture & $\begin{array}{l}\text { Chief Executive } \\
\text { Officer (CEO) }\end{array}$ & 2 years & $\mathrm{M}$ & 30 's \\
\hline B & Social venture & $\mathrm{CEO}$ & 9 years & $M$ & $30^{\prime} \mathrm{s}$ \\
\hline $\mathrm{C}$ & Social venture & CEO & 5 years & $\mathrm{M}$ & $30^{\prime} \mathrm{s}$ \\
\hline $\mathrm{D}$ & Social venture & CEO & 3 years & $\mathrm{F}$ & 30 's \\
\hline $\mathrm{E}$ & Social venture & CEO & 4 years & $M$ & 30 's \\
\hline $\mathrm{F}$ & Social venture & $\mathrm{CEO}$ & 5 years & M & $40^{\prime} \mathrm{s}$ \\
\hline G & Social venture & CEO & 5 years & M & $40^{\prime} \mathrm{s}$ \\
\hline $\mathrm{H}$ & Social venture & CEO & 6 years & M & $40^{\prime} \mathrm{s}$ \\
\hline I & Social venture & Employee & 2 years & $\mathrm{F}$ & 20 's \\
\hline $\mathrm{J}$ & Social venture & Employee & 2 years & $\mathrm{F}$ & 20 's \\
\hline $\mathrm{K}$ & Impact investment & Employee & 2 years & $\mathrm{F}$ & $30^{\prime} \mathrm{s}$ \\
\hline $\mathrm{L}$ & Impact investment & Partner & 3 years & $M$ & $40^{\prime} \mathrm{s}$ \\
\hline$M$ & Impact investment & Partner & 18 years & $\mathrm{M}$ & 50 's \\
\hline $\mathrm{N}$ & Intermediary & Employee & 1 year & $\mathrm{F}$ & $20^{\prime} \mathrm{s}$ \\
\hline $\mathrm{O}$ & Intermediary & Employee & 10 years & M & $60^{\prime} \mathrm{s}$ \\
\hline $\mathrm{P}$ & Intermediary & Employee & 10 years & $\mathrm{M}$ & $40^{\prime} \mathrm{s}$ \\
\hline
\end{tabular}

\section{Findings}

\subsection{Open Coding}

In open coding, the process of connecting categories considers the attributes and dimensions around particular categories. Categories comprise concepts derived from the data; the more concepts there are, the richer these categories become, and the more sophisticated the relationships between categories will be. In this study, open coding was performed through a line unit analysis process that examined expressions, words, and 
sentences in detail. In this process, a conceptualization was included as the same concept if it indicated the same or similar content, with a focus on the repeatability of the word. As a result of open coding 24 categories were identified (Table 3 ).

Table 3. Open coding results.

\begin{tabular}{|c|c|}
\hline Category & Original Statement \\
\hline Recognition of poverty & $\begin{array}{l}\text { "Looking at local and international communities, there are some kids that do not have } \\
\text { enough food each day" (Interviewee B) } \\
\text { "Many African young people are still suffering from absolute poverty" (D) } \\
\text { "Some high school students are not able to get tutors due to the high costs" (I) }\end{array}$ \\
\hline Recognition of disabled people & $\begin{array}{c}\text { "Just because the disabled are invisible does not mean that they do not exist in this society. } \\
\text { Most of the time, they stay at home" (B) } \\
\text { "Many disabled people live in the country, and I wondered if I could give them a chance to get } \\
\text { hired" (K) }\end{array}$ \\
\hline $\begin{array}{l}\text { Recognition of environmental } \\
\text { issues }\end{array}$ & $\begin{array}{l}\text { "I've always had a sense of environmental concern since my college years, and I thought that } \\
\text { I should go with the flow in this area" (B) }\end{array}$ \\
\hline Private support & $\begin{array}{l}\text { "Our social venture was funded by one of the few impact investors in the beginning, and we } \\
\text { receive additional investment every year" (F) }\end{array}$ \\
\hline Government support & $\begin{array}{l}\text { "Initially, I received seed money through social enterprise development projects" (A) } \\
\text { "I'm getting investment from Seoul, for example, government-funded growth financing or } \\
\text { Seoul City government-funded operating expenses" (K) }\end{array}$ \\
\hline Purpose of establishment & $\begin{array}{l}\text { "The company was established to provide quality coffee to consumers through producer } \\
\text { cooperation" (E) } \\
\text { "Our business provides farmers with all the goods and services, provides storage, and } \\
\text { receives annual fees" (F) } \\
\text { "Our social venture was established to solve the information accessibility and educational } \\
\text { inequality of the socially disadvantaged and economically vulnerable" (G) }\end{array}$ \\
\hline Generating performance & $\begin{array}{l}\text { "We are making profits by providing social services to socially disadvantaged people" (A) } \\
\text { "So far, we've planted about a million trees, and from there we are making profits" (B) } \\
\text { "I started a business for the disabled, and they are hired by my company. The treatment of } \\
\text { them is improving, (and we are) further trying to solve social problems in the community" (J) }\end{array}$ \\
\hline Awareness of lack of self-power & $\begin{array}{l}\text { "Since the business' target is rural areas, it is very difficult to meet the break-even point. It } \\
\text { costs a lot, and the foundation for solo social ventures has weakened" (A) } \\
\text { "I don't think we could have started the company without the government funding" (C) } \\
\text { "Most social ventures, from startup to financing, have become dependent on the } \\
\text { government" (O) }\end{array}$ \\
\hline
\end{tabular}

"We should keep our social values but expand the business to other cities or other countries"

A desire for business continuity and expansion

Internal networks
“I think it's important for social ventures to develop independence and self-sustainability to create a company that can survive without government funding" (B)

"I wonder if we can maintain sustainability even if government support is cut off" (C)
"The CEO needs flexibility in the organization" (D)

"The CEO needs to show his leadership skills and rational judgment to partners and employees" (F)

"The spirit and professionalism of the CEO and employees must be combined to succeed" $(G)$

"The working-level officials need to coordinate the parts one by one" (I)

"We are sharing information with CEOs of social ventures in similar industries or who started their businesses around the same time" $(\mathrm{H})$

"We're getting a lot of help from a community that has been formed among social ventures" (I) "Networks are especially important to expand in this field" (K) 
Table 3. Cont.

Category
$\begin{gathered}\text { Original Statement } \\ \text { "Social missions require a strong sense of responsibility because they help companies stay } \\ \text { flexible even in difficult business conditions" (D) }\end{gathered}$
$\begin{gathered}\text { Accountability for social missions } \\ \text { "Can a founder really solve this problem without giving up until the end? I think that's the } \\ \text { journey to success" (K) }\end{gathered}$
"It is important not to forget the initial mission and to achieve this mission" (L)
"I think the ability to discover and recognize social problems is the key factor" (A)
"It is important to find a problem and make it into a social discourse with (public) interest" (B)
"Almost all entrepreneurs have strong wills and a lack of substance, so their companies often
go bankrupt quickly" (C)

Empathy

Field experiences

Auxiliary role of the government

System improvement

Active role of intermediaries
"We are trying to generate customer empathy for solving social problems through products and services" (A)

"I learned about the importance of the work from the field" (B)

"I learned the ability to communicate with various experts in the field" (C)

"Specialized knowledge and experience are required in the industry" (E)

"I met a lot of customers and beneficiaries on the spot [who had] a sense of the problem" (K)

"I see in the field that there is a wide range of social values" $(\mathrm{N})$

"In the early days of the social venture, we worked with related NGOs. We received a lot of help through the partnership with KOICA (Korea International Cooperation Agency) when we expanded our business to developing countries" (A)

"We recently signed an MOU with a partner agency, and partnerships with other organizations are also being developed through our networks" (I)

"The government should play a role in supporting social ventures rather than regulating them" (B)

"The government should create platforms for social ventures to communicate and build up their networks" (D)

"The government should play a role in supporting and assisting the private-led social venture ecosystem" (E)

"The social venture ecosystem can be developed if various stakeholders cooperate with the intermediaries" (C)

"We are sharing a significant amount of information through exchange with intermediaries" (G)

"The intermediaries are lacking in terms of numbers and are not yet fully developed" (F)

"I think solidifying the intermediaries is an important factor for social venture growth" $(\mathrm{N})$

"The social venture guidelines from the government are very old-fashioned, so if you look at them in detail, there are a lot of mistakes" (A)

"There is a problem with social enterprise law, and it needs to be improved" (C)

"Social returns are unclear in the government guidelines" (K)

"Some social ventures abuse the word 'social', such as (when they) win government funding" $(\mathrm{O})$ 
Table 3. Cont.

\begin{tabular}{|c|c|}
\hline Category & Original Statement \\
\hline Revitalizing private investment & $\begin{array}{l}\text { "Foreign funds for social ventures must increase" (A) } \\
\text { "Social venture loans should be made easier, and resources should be properly distributed" (F) } \\
\text { "The impact investment needs to be expanded" (P) } \\
\text { "The ecosystem can be successfully established when private capital increases and is invested } \\
\text { in social ventures" (L) }\end{array}$ \\
\hline Independence of social ventures & $\begin{array}{l}\text { "Social ventures must keep neutrality and independence on their own" (B) } \\
\text { "When social ventures receive government funding, they have to meet the government's } \\
\text { standards, which creates a lot of restrictions" }(\mathrm{C}) \\
\text { "From a business perspective, social ventures should function with a bottom-up, not } \\
\text { top-down, approach" (K) }\end{array}$ \\
\hline Business continuity & $\begin{array}{l}\text { "We have identified possibilities as more and more customers are choosing our products } \\
\text { based on merchantability, not just from the perspective of solving social problems" (B) } \\
\text { "The social venture ecosystem is growing. Sales are also steadily rising, opening up new } \\
\text { markets" (K) }\end{array}$ \\
\hline
\end{tabular}

\subsection{Axial Coding}

Axial coding is the process of finding associations among the categories used in open coding. Based on the relationships of the 24 categories defined during open coding, seven subsequent categories were derived during axial coding. First, the participants described social problems largely as being related to poverty, disability, and the environment in the category of "social problem awareness". Second, private support and government support were grouped as "external investment". Third, the act of establishing or finding jobs in social ventures and creating social and economic profits through them was categorized as an "increase in social ventures". Fourth, the perception of the lack of social ventures' self-power, the pursuit of the permanence of the business, and the desire to expand were labeled as the "pursuit of sustainability".

Fifth, various factors emerged regarding enhancing the capacity of social ventures, which were divided into "external and internal capacity building" factors. Internal factors were shown to be the organization, internal network, accountability for the social mission, capability to find social problems, innovation, implementation, and empathy. The external factors were field experience and the external network. Sixth, the research participants emphasized the demands on governments to perform auxiliary roles. In addition, the activation of intermediaries, improvement of the government system, revitalization of private investment, and the independence of social ventures were categories relating to government policy. Finally, statements regarding securing and expanding the sustainability of social venture businesses were grouped into the "formation of sustainable ecosystems for social ventures". The relationship between the seven categories and the content corresponding to each is shown in Table 4.

In the axial coding phase, a paradigm model was constructed in which the causal condition is 'social problem awareness', and the contextual conditions refer to 'external investment', where the central phenomenon is an 'increase in social ventures', where intervening conditions refer to the 'pursuit of sustainability', where actions/interactions relate to 'internal and external capacity building' and 'a demand for government support', and where the consequences are the 'formation of a sustainable ecosystem for social ventures' (Figure 1). 
Table 4. Axial coding results.

\begin{tabular}{|c|c|c|}
\hline Main Category & Subcategory & Initial Concept \\
\hline \multirow{3}{*}{$\begin{array}{l}\text { Social problem } \\
\text { awareness }\end{array}$} & Recognition of poverty & Perception of domestic and global poverty issues. \\
\hline & Recognition of disabled people & $\begin{array}{l}\text { Awareness of reasons for the alienation of the disabled. Desire to } \\
\text { improve the welfare of the disabled. }\end{array}$ \\
\hline & Recognition of environmental issues & $\begin{array}{l}\text { Interest in solving environmental problems. } \\
\text { Reducing the cost of the disposal of environmental waste. }\end{array}$ \\
\hline \multirow{2}{*}{$\begin{array}{c}\text { External } \\
\text { investment }\end{array}$} & Private support & $\begin{array}{l}\text { Obtaining impact investment. } \\
\text { Creating a situation in which impact investment can continuously } \\
\text { support social ventures. }\end{array}$ \\
\hline & Government support & $\begin{array}{l}\text { Government's financial support policy for social ventures. } \\
\text { Support from the city government to which each social } \\
\text { venture belongs. }\end{array}$ \\
\hline \multirow[t]{2}{*}{$\begin{array}{l}\text { Increase in } \\
\text { social ventures }\end{array}$} & Purpose of establishment & $\begin{array}{l}\text { Establishment of social ventures in accordance with the desire to } \\
\text { provide better quality products. } \\
\text { Benefits to producers due to social ventures. Establishment of social } \\
\text { ventures in accordance with the desire to distribute benefits to the } \\
\text { socially disadvantaged. } \\
\text { Willingness to solve environmental problems by establishing } \\
\text { social ventures. }\end{array}$ \\
\hline & Generating performance & $\begin{array}{l}\text { Creating social value outcomes. } \\
\text { Generating financial profits. }\end{array}$ \\
\hline \multirow{2}{*}{$\begin{array}{c}\text { Pursuit of } \\
\text { sustainability }\end{array}$} & Awareness of lack of self-power & $\begin{array}{l}\text { Lack of self-sufficiency due to financial limitations. Perception of } \\
\text { overdependence on the government. }\end{array}$ \\
\hline & $\begin{array}{l}\text { A desire for business continuity and } \\
\text { expansion }\end{array}$ & $\begin{array}{l}\text { Desire to expand international business. } \\
\text { Desire to continue business operations. } \\
\text { Will to discover new investment sectors. }\end{array}$ \\
\hline \multirow{9}{*}{$\begin{array}{l}\text { Internal and } \\
\text { external } \\
\text { capacity } \\
\text { building }\end{array}$} & $\begin{array}{c}\text { Internal: } \\
\text { Organization }\end{array}$ & $\begin{array}{l}\text { CEO's leadership skills and employees' teamwork. } \\
\text { The role of individuals as members of the organization. }\end{array}$ \\
\hline & $\begin{array}{l}\text { Internal: } \\
\text { Internal networks }\end{array}$ & $\begin{array}{l}\text { Social ventures helping each other in the community. Forming an } \\
\text { internal network to expand the business. }\end{array}$ \\
\hline & $\begin{array}{l}\text { Internal: } \\
\text { Accountability for social mission }\end{array}$ & $\begin{array}{l}\text { Responsibility for social problems. } \\
\text { Determination to solve missions. } \\
\text { Persistence of beliefs. }\end{array}$ \\
\hline & $\begin{array}{l}\text { Internal: } \\
\text { Capability to find social problems }\end{array}$ & $\begin{array}{l}\text { Ability to detect problems. } \\
\text { Ability to socialize problems. } \\
\text { Analysis of current market conditions to cope with social problems. }\end{array}$ \\
\hline & $\begin{array}{l}\text { Internal: } \\
\text { Innovation }\end{array}$ & $\begin{array}{l}\text { Ability to generate community benefits. } \\
\text { Technological innovation. } \\
\text { Scarcity. } \\
\text { Ideas and competitiveness using limited resources. }\end{array}$ \\
\hline & $\begin{array}{c}\text { Internal: } \\
\text { Implementation }\end{array}$ & $\begin{array}{l}\text { Willingness to carry out business. } \\
\text { Driving force to solve problems. }\end{array}$ \\
\hline & Internal: Empathy & The ability to empathize with society and its problems. \\
\hline & $\begin{array}{l}\text { External: } \\
\text { Field experiences }\end{array}$ & $\begin{array}{l}\text { Recognition of real social problems through field experience. } \\
\text { Expertise learned in the field. } \\
\text { Meetings with people who are experiencing real social problems. } \\
\text { Recognition of the scope of social values in the field. }\end{array}$ \\
\hline & External: Organizational network & $\begin{array}{c}\text { Building local partnerships. } \\
\text { Sharing knowledge through institutional cooperation. Signing } \\
\text { MOUs. }\end{array}$ \\
\hline
\end{tabular}


Table 4. Cont

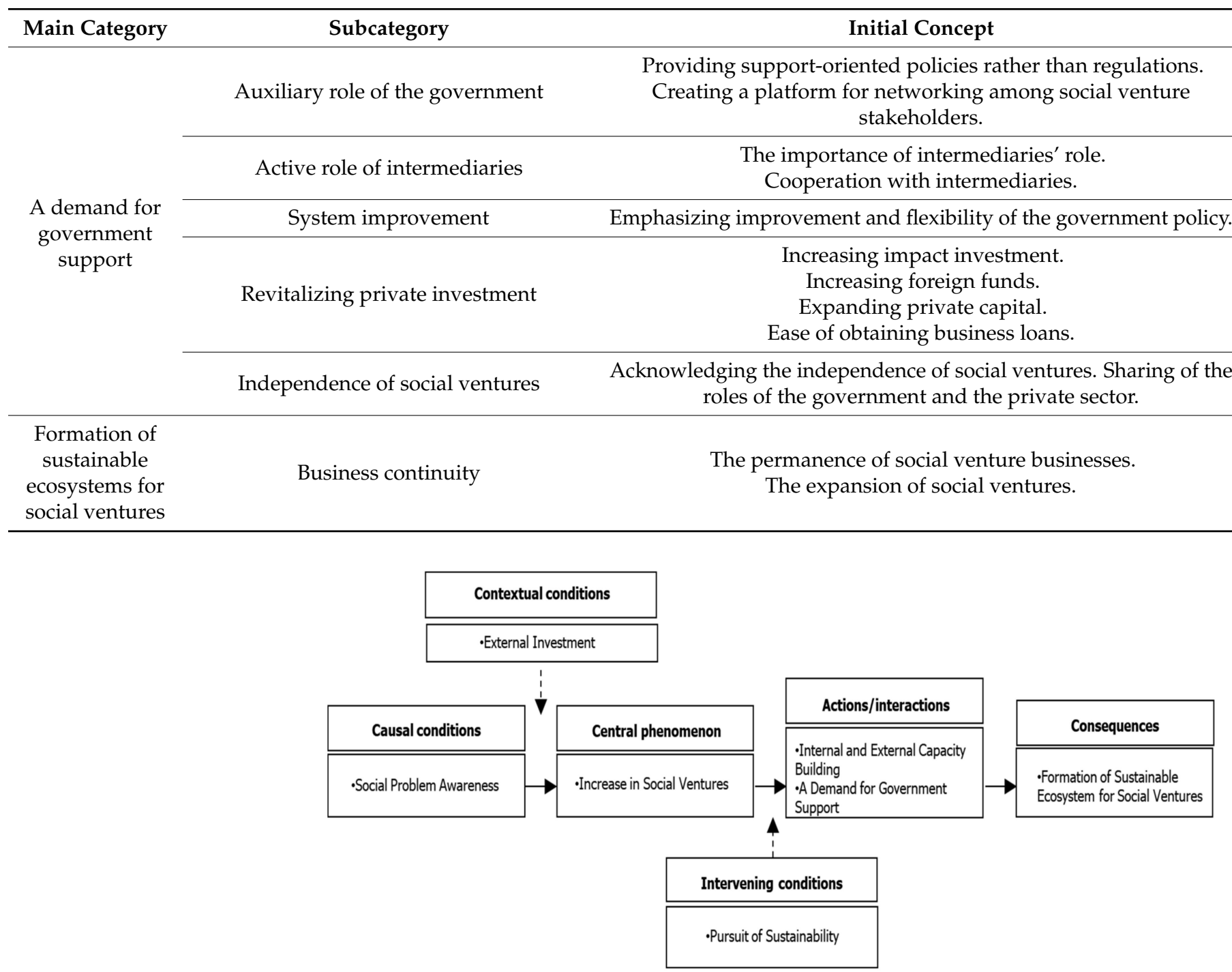

Figure 1. Paradigm model of the present study.

\subsection{Selective Coding}

Selective coding is the methodical step of integrating categories that have been connected through axial coding and elaborating them into theory. At this stage, the key research categories are identified, associations with other categories are defined, and the categories are described. These processes can develop new types of theories about research problems by forming and embodying the relationships between concepts based on the results previously presented through open and axial coding.

In this study, the results are related to the formation of a sustainable ecosystem for social ventures. The researchers came to recognize the problems in society's current situation as they observed social problems such as poverty (international poverty, domestic social poverty, stigma about poverty, etc.), disability (alienation of the disabled, improvement of welfare, etc.), and environmental issues (reduction of environmental waste disposal costs, solving environmental problems). As a result, participants became aware of social problems at home and abroad. In this context, government funding and impact investment were made during the founding and growth of social ventures. This outside financial support enabled social ventures to realize social value and led to an increase in social venture companies generating socio-economic results. In this process, the number of social venture companies was increased. 
However, participants were aware that the social venture ecosystem was not yet properly formed and that social ventures lacked self-sustaining power. While discovering new investment sectors or raising their voices for business expansion and continuous leadership, participants also expressed anxiety and fear about sustainability. To this end, participants reinforced their internal and external competencies, and the government made various efforts for the success of social ventures. The internal competencies of social ventures are to develop organizational skills such as rational judgment and leadership, cooperation, and teamwork among the members of the organization. And it is improved by building the same network as the new organizational structure. Individuals also increased their social responsibility and ability to find problems, such as analyzing the market environment and raising issues.

Participants further cited innovation, implementation, and empathy as critical factors for building capabilities. External capabilities have been identified through multiple field experiences and the establishment of external networks. The research participants stressed the need to further boost impact investment, noting that successful impact investment is now underway. They also mentioned the role of the government in recognizing and supporting the independence of social ventures. Currently, the government is mainly implementing regulatory policies, but it is important to support social ventures with other policies such as providing support-oriented incentives and a place to establish a cooperative network system at the same time. As there are currently few intermediaries, the respondents emphasized the need to continue social venture business by activating intermediaries and mentioned the need to improve the social venture government system. In particular, when improving the system, flexibility was emphasized for efficient management. Social venture companies aimed for a bottom-up method and emphasized the need to share their government roles. As a result, social ventures have been able to expand their business and create a sustainable ecosystem.

\section{Discussion and Conclusions}

\subsection{Discussion}

This study analyzed existing studies and conducted in-depth interviews with entrepreneurs, employees, and stakeholders regarding the sustainable and successful ecosystem formation, maintenance, and development of social ventures. The results obtained by conducting research using qualitative research methods can be summarized as follows. Entrepreneurship, the competence of entrepreneurs in social ventures, plays a key role, discovering ideas and opportunities for businesses and completing business models to ensure specific commercialization. The leaders armed with entrepreneurship, such as creativity, innovation, and risk-taking, can initiate and continue a project by mobilizing all their capabilities, including technology and marketing capabilities. From there, the importance of networks that utilize corporate resources such as cooperation with other social ventures by sharing knowledge and technology is highlighted from the early stage of their start-ups. Social ventures maximize internal factors such as human resources, $\mathrm{R} \& \mathrm{D}$, technological advances, building professional know-how, and trying to reduce the burden of failure and increase the likelihood of success through continuous networks with other stakeholders. In addition, securing a growth engine with support from the government, intermediary agencies, and impact investors also creates a virtuous cycle in which entrepreneurs' spirit of challenge and willingness to succeed increases.

Entrepreneurs' awareness and willingness to solve social problems also leads to a sense of challenge, and the formation and maintenance of business models in the preparation stage positively affects the performance of social ventures through internal corporate resources and external cooperation. For the successful implementation of a project and sales improvement from it, corporate resources such as entrepreneurship and innovative technologies of social ventures and strongly tied networks with stakeholders can be expected. Above all, the role of government organizations is very important in taking a leap forward in social ventures. The role of government is to secure investment credibility 
in social ventures through social venture evaluations process by public or private evaluation organizations. Therefore, it is necessary to develop and introduce an evaluation policy according to the essential elements of social innovation at the government level in accordance with the conceptualization of social ventures. In the expansion phase of social ventures, the roles of impact investment organizations and incubating organizations are seen to be significant. Their support for market development can expand the application of the products or services of social ventures.

Factors necessary for the successful establishment of social venture ecosystems in the case of other countries can be found in China, including entrepreneurship and technological innovation as internal factors, entrepreneurs' accountability, implementation, and empathy for their social mission [40,45]. In India, external environments, such as close networks of government and nongovernmental organizations, cooperation with impact investment organizations, and sociocultural values are cited as key factors [46]. The sociocultural elements necessary for social ventures do not arise by chance, but by the ability of entrepreneurs to change sociocultural values to match their own plans and pursuits when performing their roles as entrepreneurs.

\subsection{Theoretical Contributions}

The academic contribution of this study lies in its innovative in-depth approach to the existing literature surrounding Korean social ventures through the use of grounded theory and the expansion of its scope. The existing research has not previously examined a wide range of social ventures, and there is some limit to the in-depth research that fully reflected their domestic characteristics. In addition, most of the studies on social ventures have focused on European or American cases. This study is, therefore, meaningful in that it presents the concept of social venture based on literature review and the opinions of domestic interviewees in the legal and academic ambiguous situation of social ventures in Korea.

This study is also theoretically meaningful in that it has subdivided the success factors of social ventures. Social ventures have been able to succeed through various independent efforts to pursue sustainability due to insufficient government systems or a lack of self-sustaining power. Although existing domestic research has focused on significant success factors such as entrepreneurship and technical competence, this study defined other relevant internal and external factors. The specific factors related to social ventures derived from this study may be used as the basis for future research. In addition, through in-depth interviews with Korean social entrepreneurs and stakeholders, data were collected and analyzed to produce research results suitable for the situation in Korea. Above all, it is of academic significance in that it presents a diversified dynamic concept of sustainability of social ventures compared to previous studies, which were only fragmented.

\subsection{Managerial Implications}

The social entrepreneurs and stakeholders should reflect the fact that the formation and utilization of their resources in the preparation phase of social ventures have a positive impact on corporate structures and external networks. In addition, the government should continue to support effective policy development and programs that help social ventures with business models actively engaging in social venture activities and demonstrate their abilities through a spirit of challenge. Support policies for the formation and utilization of social venture business models should be implemented continuously, such as entrepreneurs drawing up ideas for new businesses, preparing products or services, and receiving impact funds necessary for those businesses. Through this, social ventures will be able to strengthen corporate resources and establish networks with other social ventures.

Currently, social venture-related policies are being implemented in a top-down manner in Korea, infringing on corporate autonomy and causing social ventures to lose their independence. For the success of social ventures, the government must recognize their role. The government needs to provide an environment for publicizing "social problems" in an 
official setting, which will form a cooperative body. Establishing a sustainable ecosystem through indirect policy support for the development of social ventures should also be considered, for example, by providing a platform for developing internal and external networks. In addition, the government should consider ways to enhance the level of enterprises by supporting the training of professionals. The professional training of social venture workers improves their job skills, which can enhance business sustainability.

Moreover, social venture entrepreneurs and employees must strengthen their internal capabilities to successfully lead these enterprises. To strengthen their ability to solve social problems, professional knowledge should be accumulated through sufficient field experience. It is also necessary to strengthen the internalization of social ventures by fortifying their mission to solve social problems, their technical ability, and their innovation. Entrepreneurs should endeavor to enhance their leadership to manage the organization well and to have an eye for rational judgment, and, through this, the social venture itself can strengthen its sustaining power. Forums, partnerships, or education programs that strengthen internal resources from the perspective of social ventures can increase management performance by cooperating with partner companies, so strategies and implementations from intermediary agencies are needed to strengthen corporate resources.

\subsection{Limitations and Future Research}

This study has some limitations. First, it was conducted with a single case, a social venture in Korea, and it is difficult to generalize findings regarding social ventures to the context of other countries in which the concept may differ slightly. Second, since this study was conducted with a social venture, its results might apply in various ways to general enterprises and are, therefore, also difficult to generalize in this regard. Finally, this research was conducted as an exploratory study using grounded theory. Our future research will seek to further define the relationship between sustainable success factors and the ecosystem formation process of Korean social ventures based on quantitative analysis.

Author Contributions: Conceptualization, J.K. and J.L.; methodology, J.L.; software, J.L.; validation, J.K. and T.J.L.; formal analysis, J.K.; investigation, J.K. and J.L.; resources, J.K.; data curation, J.K.; writing-Original draft preparation, J.K. and J.L.; writing-review and editing, T.J.L.; visualization, T.J.L.; supervision, T.J.L.; project administration, J.K.; funding acquisition, J.K. All authors have read and agreed to the published version of the manuscript.

Funding: This research was funded by the University of Suwon in 2018.

Institutional Review Board Statement: The study was conducted according to the guidelines of the Declaration of Helsinki, and approved by the Institutional Review Board of the University of the Suwon (20 March 2021).

Informed Consent Statement: Informed consent was obtained from all subjects involved in the study.

Conflicts of Interest: The authors declare no conflict of interest. The funders had no role in the design of the study; in the collection, analyses, or interpretation of data; in the writing of the manuscript, or in the decision to publish the results.

\section{Appendix A}

Interview Questions

1. What is this establishment's background and motivation (employment background and motivation)?

2. What are the main characteristics of social ventures and entrepreneurs?

3. What do you think are your core competencies as a social venture and entrepreneur?

4. What are the differences between social enterprises and social ventures?

5. Why did you choose this business model, rather than nonprofit methodologies, to solve social problems?

6. What competencies are most needed among entrepreneurs and employees for the success of social ventures? 
7. What are the differences between general ventures and social ventures?

8. Are you receiving government support (subsidies and funds)? If yes, how helpful was it?

9. (If interviewee answered "no" in No. 8) Why are you not receiving government assistance?

10. How do you plan to maintain corporate survival once government support is completed?

11. Is your social venture government certified? What are the reasons?

12. Is your social venture obtaining funds from impact investment?

13. Do you have partnerships with other intermediaries or organizations to create social and economic value? If so, how do you cooperate with each other?

14. What do you think about government-led support for social ventures?

15. Do you think investment models of general start-ups or ventures, such as incubation and acceleration, should be applied to social ventures? Why or why not?

16. Do you have any private-led ideas for building a social venture ecosystem?

17. What are the main strategies, decision-making methods, and marketing policies of social ventures?

18. What products/services are offered for social/economic benefits in social ventures? What is the background of this product/service?

19. How is the research and development of innovative technologies or products and services taking place?

20. What challenges did you face in the operational process and how did you overcome them?

21. Is there a strategy for creating sustainability in this social venture?

22. What do you think is the main innovation of social ventures (new markets, new products, new methods)?

23. Who are the biggest beneficiaries of the products/services offered to realize the company's social/economic value and why?

24. Were there conflicts in the realization of social and economic values?

25. How should a sustainable ecosystem for social ventures be built (the need for system change)?

\section{References}

1. European Commission. A Map of Social Enterprises and Their Ecosystems in Europe-Country Report for Germany, London: CF Consulting Services. 2016. Available online: https: / / ec.europa.eu/social/ main.jsp?catId=738\&langId=en\&pubId=8274 \&furtherPubs=yes (accessed on 28 November 2020).

2. Borzaga, C.; Defourny, J. The Emergence of Social Enterprise; Routledge: London, UK, 2001; pp. 1-18.

3. Sung, J.; Hwang, J.W.; Ahn, J.A. Study on the Revitalization of Social Enterprises through Social Venture Support; Korea University of Technology and Education R \& DB Foundation: Seoul, Korea, 2014.

4. Choi, H.G. An exploratory research on the sustainable successful business model in social enterprise. Korean Revenue Manag. Consul. 2017, 8, 161-176. [CrossRef]

5. Lee, D.H. A case study on the social enterprise: Let's go fair travel. Soc. Enterpr. Stud. 2016, 9, 157-183.

6. Small and Medium Business Research Institute. A Study on the Development of Social Venture for the Revitalization of Social Economy 2018. 2018. Available online: http:/ / www.alio.go.kr/informationResearchView.do?seq=2420604 (accessed on 15 July 2020).

7. Glaser, B.G.; Strauss, A.L.; Strutzel, E. The discovery of grounded theory; Strategies for qualitative research. Nurs. Res. 1968, 17, 364. [CrossRef]

8. Strauss, A.; Corbin, J. Grounded theory methodology: An overview. In Handbook of Qualitative Research; Denzin, N.K., Lincoln, Y.S., Eds.; Sage: London, UK, 1994; pp. 1-18.

9. Streubert, H.J.; Carpenter, D.R. Qualitative Research in Nursing: Advancing the Humanistic Imperative; Lippincott Williams \& Wilkins: London, UK, 1995.

10. Na, J.J. A Study on Fostering and Supporting of Social Venture for Social Economic Activation: Focusing on the Case Seongdonggu, Seoul. Master's Thesis, Hanyang University, Seoul, Korea, 2019. Unpublished.

11. García-Jurado, A.; Pérez-Barea, J.J.; Nova, R.J. A new approach to social entrepreneurship: A systematic review and meta-analysis. Sustainability 2021, 13, 2754. [CrossRef] 
12. National Endowment for Science, Technology and the Arts (NESTA). Investing Innovative Social Venture: A Practice Guide. 2015. Available online: https://media.nesta.org.uk/documents/investing_in_innovative_social_ventures-_a_practice_guide-final.pdf (accessed on 25 March 2021).

13. Păunescu, C.; Molnar, E. Country's entrepreneurial environment predictors for starting a new venture-Evidence for Romania. Sustainability 2020, 12, 7794. [CrossRef]

14. Haugh, H. Community-led social venture creation. Entrep. Theory Pract. 2007, 31, 161-182. [CrossRef]

15. Hockerts, K. Entrepreneurial Opportunity in Social Purpose Business Ventures. In Social Entrepreneurship; Mair, J., Robinson, J., Hockerts, K., Eds.; Palgrave Macmillan: London, UK, 2006.

16. Dees, J.G.; Anderson, B.B. For-profit social ventures. Int. J. Entrep. Educ. 2003, 2, 1-26.

17. Alter, K. Social enterprise typology. Virtue Ventur. LLC 2007, 12, 1-124.

18. Zhu, R.; Sun, S.L. Fostering generative partnerships in an inclusive business model. Sustainability 2020, 12, 3230. [CrossRef]

19. Westall, A. Value Led, Market Driven-Social Enterprise Solutions to Public Policy Goals; Institute of Public Policy Research: London, UK, 2001.

20. Bae, T.J.; Fiet, J.O. Imprinting perspective on the sustainability of commitments to competing institutional logics of social enterprises. Sustainability 2021, 13, 2014. [CrossRef]

21. Mort, G.S.; Weerawardena, J.; Carnegie, K. Social entrepreneurship: Towards conceptualization. Int. J. Nonprofit Volunt. Sect. Mark. 2003, 8, 76-88. [CrossRef]

22. Gault, F. Innovation Strategies for a Global Economy; International Development Research Centre: Ottawa, QC, Canada, 2010.

23. Abu-Saifan, S. Social entrepreneurship: Definition and boundaries. Technol. Innov. Manag. Rev. 2012, 2, 22-27. [CrossRef]

24. Estrin, S.; Mickiewicz, T.; Stephan, U. Human capital in social and commercial entrepreneurship. J. Bus. Ventur. 2016, 31, 449-467. [CrossRef]

25. Fernández-Laviada, A.; López-Gutiérrez, C.; Pérez, A. How does the development of the social enterprise sector affect entrepreneurial behavior? An empirical analysis. Sustainability 2020, 12, 826. [CrossRef]

26. Geels, F.W. From sectoral systems of innovation to socio-technical systems: Insights about dynamics and change from sociology and institutional theory. Res. Policy 2004, 33, 897-920. [CrossRef]

27. Ieromonachou, P.; Potter, S.; Enoch, M. Adapting strategic niche management for evaluating radical transport policies: The case of the Durham Road Access Charging Scheme. Int. J. Transp. Manag. 2004, 2, 75-87. [CrossRef]

28. Kang, M.J. A study on promoting social venture and impact investment. Korea Bus. Rev. 2012, 16, $263-282$.

29. Choi, Y.S.; Baek, B.H. Strategies for revitalizaing social venture ecosystem based on social innovation theory. Asia-Pac. J. Bus. Ventur. Entrep. 2020, 15, 1-17.

30. Austin, J.; Stevenson, H.; Wei-Skillern, J. Social and commercial entrepreneurship: Same, different, or both? Rev. Adm. 2012, 47, 370-384. [CrossRef]

31. Hunt, R.A. Contagion entrepreneurship: Institutional support, strategic incoherence, and the social costs of over-entry. J. Small Bus. Manag. 2015, 53, 5-29. [CrossRef]

32. Porter, M.E. Locations, Clusters and Company strategy. In The Oxford Handbook of Economic Geography; Harvard Business School: Boston, MA, USA, 2000; pp. 253-274.

33. Tanimoto, K. A conceptual framework of social entrepreneurship and social innovation cluster: A preliminary study. Hitotsubashi J. Commer. Manag. 2008, 42, 1-16.

34. Lee, Y.R.; Lee, M.H. The analysis of local community by network effect of social enterprises: Focusing on Social Venture Valley in Seongsu-dong area. J. Korean Reg. Dev. Assoc. 2017, 29, 161-187.

35. Yoon, B.S.; Seo, Y.W. Effects of startup activities of preparatory stage and early stage on performance. Asia-Pac. J. Bus. Ventur. 2016, 11, 1-15.

36. TEPSIE. Social Innovation Theory and Research: A Guide for Researchers. 2014. Available online: https://youngfoundation.org/ wp-content/uploads/2015/04/YOFJ2785_Tepsie_A-guide_for_researchers_06.01.15_WEB.pdf (accessed on 23 March 2021).

37. Vignoli, F.; de Luca, C.; Tondelli, S. A spatial ecosystem services assessment to support decision and policy making: The case of the city of Bologna. Sustainability 2021, 13, 2787. [CrossRef]

38. Wilson, K.E. New Investment Approaches for Addressing Social and Economic Challenges; OECD Science, Technology and Industry Policy Papers, No. 15; OECD Publishing: Paris, France, 2014. [CrossRef]

39. Shanmugalingam, C.; Graham, J.; Tucker, S.; Mulgan, G. Growing social ventures. In The Role of Intermediaries and Investors: Who They Are, What They Do, and What They Could Become; NESTA: London, UK, 2011.

40. Vuong, Q.H.; Napier, N.K. Acculturation and global mindsponge: An emerging market perspective. Int. J. Intercult. Relat. 2015, 49, 354-367. [CrossRef]

41. Stephan, U.; Uhlaner, L.M.; Stride, C. Institutions and social entrepreneurship: The role of institutional voids, institutional support, and institutional configurations. J. Int. Bus. Stud. 2015, 46, 308-331. [CrossRef]

42. Campanale, C.; Savino, I.; Pojar, I.; Massarelli, C.; Uricchio, V.F. A practical overview of methodologies for sampling and analysis of microplastics in riverine environments. Sustainability 2020, 12, 6755. [CrossRef]

43. Flick, U. An Introduction to Qualitative Research; Sage Publications: Thousand Oaks, CA, USA, 2018.

44. Browne, K. Snowball sampling: Using social networks to research non-hetero sexual women. Int. J. Soc. Res. Method 2005, 8 , 47-60. [CrossRef] 
45. Tian, Q.; Zhang, S.; Yu, H.; Cao, G. Exploring the factors influencing business model innovation using grounded theory: The case of a Chinese high-end equipment manufacturer. Sustainability 2019, 11, 1455. [CrossRef]

46. Agarwal, S.; Lenka, U.; Singh, K.; Agrawal, V.; Agrawal, A.M. A qualitative approach towards crucial factors for sustainable development of women social entrepreneurship: Indian cases. J. Clean. Prod. 2020, 274, 123135. [CrossRef] 